\title{
The Effects Of Some Agricultural Development Programme (Adp) Inputs To Rural Farmers Productivity And Income.
}

\author{
${ }^{1}$ Amadi, D.C.A; ${ }^{1}$ Saka M.G; and ${ }^{1}$ Jatau D.F. \\ ${ }^{I}$ Department of Forestry and Wildlife Management, Modibbo Adama University of Technology, Yola.
}

\begin{abstract}
The Agricultural Development Program (ADPs) is one of the institutions set up by the Federal Government of Nigerian to undertake specific rural development activities in rural areas whose preponderance population are farmers. (Ariyo 1991, Olusegun 1991, Irag 1986, Chambers1993, Ekpo and Olanyi 1995). One of the critical determinants of rural development is change in productivity and income. This paper therefore examined the effects of some ADP inputs on rural farmers' productivity and income in Adamawa state of Nigeria as an attempt to validate ADP's contribution to rural development. Data on crop yield, farm income, and facilities provided by the ADP such as roads, irrigation facilities, farm inputs and loan facility were collected from a total of 435 farmers in 2006 2009, and 2012. The data generated were analyzed using regression analysis (MINITAB). Results show that both crop yield and farm income were positively influenced by irrigation facilities and loan amount, while good rural roads facilitated easy access of agricultural produce to markets. The implication is that agricultural productivity and income could be greatly improved in Nigeria if irrigational facility is generally provided as well general empowerment of rural farmers under the denominator of good rural road network.
\end{abstract}

Keywords: Productivity, ADP inputs, farm income.

\section{Introduction}

Nigeria had labored and is still laboring to perk up agriculture and standard of living of small scale rural farmers. The agricultural sector is still dominated by rural dwellers. These rural dwellers produce over $80 \%$ of the country's food requirement (Amao et al 2003). According to Alimi (2000), productivity is the translation of input(s) into output(s). Many authors (Ogunfowora et al (1975), Ladipo and Leigh (1979), Cleaver (1993) and UN (2001) had reported stumpy productivity of Nigerian's agricultural sector.

The need to improve the rural farmers productivity, income and standard of living led to the establishment of state wide ADPs. Most erudite attempt to evaluate the performance of ADP and other rural development institutions had reported that their achievements are unimpressive when set against the cost of the projects they have executed (Ariyo (1991) Salau (1986), Kolawole (1989), Lyam (1990). The question is then to what extent has the ADPS improved rural farmers productivity and income in their areas of location.

Therefore the need to investigate the influence of various inputs of ADP on rural farmers productivity and income necessitated this paper.

\section{Methods}

The study was carried out in Adamawa State of Nigeria, covering all the 21 local government Areas. The state has a population of 2,102,053 people spread over 38,741 square kilometers. The landform type and climate conditions favor tropical agriculture. The major vegetation type is the southern Guinea Savanna, the Northern Guinea Savanna and the Sahel Savanna. (Akosim et al 1999). Food and cash crops grown include cereals, legumes, root crops, cotton, groundnut and sugar cane. (Sajo and Kadams 1999). There is also a wide variety and concentration of livestock in the state.

A total 435 rural farmers were randomly selected and questionnaire administered to them. The ADP management was also interviewed to identify the successful areas of input provision to rural farmers. Data on crop yield, farm income, farm size, rural road construction and maintenance, irrigational facilities and loan facilities were collected in 2006, 2009 and 2012.

The data generated were analyzed using descriptive statistics such as tabular presentation and percentages. The multiple regression analysis (MINITAB Package) were further used to determine the influence of the independent variables (road, irrigational facilities, water pump, loans) on the dependent variables (crop out put and farm income).

The regression analysis is presented in the equation: $\mathrm{Y}=\mathrm{f}\left(\mathrm{x}_{1}+\mathrm{x}_{2}+\mathrm{x}_{3}+\mathrm{x}_{4}+\mathrm{x}_{5}+\mathrm{x}_{6}+\mathrm{x}_{7}\right) \mathrm{e}$

Where:

$\mathrm{Y}=$ Crop yield $/$ income

$\mathrm{x}_{1}=$ Roads

$\mathrm{x}_{2}=$ Culverts 
$\mathrm{x}_{3}=$ Table wells

$\mathrm{x}_{4}=$ Wash bores

$\mathrm{x}_{5}=$ Water pumps

$\mathrm{x}_{6}=$ Loan Amount

$\mathrm{x}_{7}=$ Extension Agents

$\mathrm{e}=$ Error term

\section{Results}

Results indicated that the social characteristics of the rural farmers consisted of 37 percent with primary education as their highest qualification, 23 percent with secondary education, 5 percent had university education, while 18 percent are illiterate. This indicates huge work for the extension workers for the rural farmers to adopt innovations. 77 percent of the respondents are males while 21 percent are females (Table1). This does not imply that male farmers are more in number than female farmers, rather the male heads of household were asked to respond to the questionnaires. The females only responded where the males were not available. The regression analysis (Table 2) shows the effects of inputs such as road construction and maintenance, $\left(\mathrm{x}_{1}\right)$ culvert construction $\left(\mathrm{x}_{2}\right)$, table well construction $\left(\mathrm{x}_{3}\right)$, wash bores $\left(\mathrm{x}_{4}\right)$, water pump $\left(\mathrm{x}_{5}\right)$, loan $\left(\mathrm{x}_{6}\right)$ and extension agents $\left(\mathrm{x}_{7}\right)$ on crop yield. Rural road construction /maintenance and extension agents had negative coefficients, while irrigational facilities and loan had positive coefficients on crop yield. The implication is that as irrigational facility and loan to rural farmers are increased, their productivity equally increases. However, only loan was found to be significant at 5 percent level. This implies that the amounts of loan received are important for the productivity of rural farmers. As the loan is increased, productivity of rural farmers also increases.

On the other hand, Table 3 shows the effect of road construction/ maintenance culverts, table well, wash bores, water pumps, loan and extension agents on farm income. Here road, culverts, irrigational facilities and extension agents all had negative coefficients while wash bores and loan had positive coefficients on farm income. This means that farm income will increase with increase in wash bores and access to credit facilities. However, none of them were significant.

\section{Conclusion and Recommendation}

The result of this study exposes the importance of capital / access to credit facility and irrigational facilities to the productivity and income of rural farmers. Access to credit facility will not only enable farmers to undertake all farm activities at and as when due, but will also enable them gainfully access all quality farm inputs. On the other hand, irrigational facilities will equip the farmers for dry season farming thereby ensuring steady income all the year round. This is important since lack of soil water favors desertification leading to crop failure (Amadi et al 2011)

It is therefore recommended that the federal government of Nigeria set machinery in motion to irrigate majority of farm lands in the country. This will also encourage dry season farming. Secondly, Government should empower the farmers with bastardized interest loan facilities to enhance profitable farm activities.

Tables

Table 1 Characteristics of respondents

Sex Educational Background

\begin{tabular}{l|llllllll}
\hline Year & No. of Resp. & Male & Female & None & Prim. & Sec. & Poly. & Univ. \\
\hline 1991 & 114 & 90 & 28 & 30 & 37 & 25 & 14 & 7 \\
1997 & 198 & 154 & 46 & 42 & 71 & 39 & 39 & 9 \\
2003 & 123 & 93 & 29 & 14 & 51 & 35 & 16 & 6 \\
Total & 435 & 337 & 98 & 86 & 159 & 99 & 69 & 22 \\
\hline$\%$ & $100 \%$ & $77 \%$ & $23 \%$ & $18 \%$ & $37 \%$ & $23 \%$ & $15 \%$ & $5 \%$ \\
\hline
\end{tabular}

Source Field data

Table 2 Regression on Crop Yield

\begin{tabular}{l|ll}
\hline Predictor Constant & Standard Deviation & Coefficient \\
\hline Roads $\left(\mathrm{x}_{1}\right)$ & 185.9 & $-17.2^{\mathrm{ns}}$ \\
Culverts $\left(\mathrm{x}_{2}\right)$ & 1163 & $246^{\mathrm{ns}}$ \\
Table well $\left(\mathrm{x}_{3}\right)$ & 1055 & $1930^{\mathrm{ns}}$ \\
Wash bores $\left(\mathrm{x}_{4}\right)$ & 543.5 & $372.0^{\mathrm{ns}}$ \\
Water pumps $\left(\mathrm{x}_{5}\right)$ & 282.4 & $406.7^{\mathrm{ns}}$ \\
Loan amount $\left(\mathrm{x}_{6}\right)$ & 15.98 & $35.86^{*}$ \\
\hline Extension agent $\left(\mathrm{x}_{7}\right)$ & 66.95 & $-64.46^{\mathrm{ns}}$ \\
\hline
\end{tabular}

$\mathrm{ns}=$ Not significant 
$*$ Significant at $5 \%(\mathrm{p}=0.05)$

Table 3 Regression on Farm Income

\begin{tabular}{|l|l|l|}
\hline Predictor Constant & Standard Deviation & Coefficient \\
\hline Roads $\left(\mathrm{x}_{1}\right)$ & 29.94 & $-2.38^{\mathrm{ns}}$ \\
\hline Culverts $\left(\mathrm{x}_{2}\right)$ & 187.4 & $-2.1^{\mathrm{ns}}$ \\
\hline Table well $\left(\mathrm{x}_{3}\right)$ & 170.0 & $-1.6^{\mathrm{ns}}$ \\
\hline Wash bores $\left(\mathrm{x}_{4}\right)$ & 87.56 & $41.58^{\mathrm{ns}}$ \\
\hline Water pumps $\left(\mathrm{x}_{5}\right)$ & 45.50 & $11.97^{\mathrm{ns}}$ \\
\hline Loan amount $\left(\mathrm{x}_{6}\right)$ & 2.575 & $3.343^{\mathrm{ns}}$ \\
\hline Extension agent $\left(\mathrm{x}_{7}\right)$ & 10.79 & $-7.03^{\mathrm{ns}}$ \\
\hline
\end{tabular}

ns $=$ Not significant

$*=$ Significant at $5 \%(\mathrm{p}=0.05)$

$* *=$ Significant at $1 \%(\mathrm{p}=0.01)$

\section{References}

[1] Akosim C, Tella I.O \& Jatau DF (1999) Vegetation and Forest Resources. In Adebeyo A.A and Tukur A.L (eds) Adamawa State in Maps Yola - Nigeria, paraclete publishers.

[2] Alimi T. (2005) Resources use efficiency in food crop production in Oyo State of Nigeria. In Journal of Agriculture and environment. Vol. 1 No. 1 June 2005 pp $1-7$

[3] Amadi, D.C.A., Nwagboso, N.K., Kwaga, B.T. and Akosim C. (2011) Human Coping Strategies to Desertification in Yobe State, Nigeria. Animal Research International 8(3) 1439-1444. 2011

[4] Amao J.O, Adebayo O.O and Ayanwuyi E (2003). Analysis of Factors Affecting Income Generation Among Farmers' Group in Ilorin East Local Government Area of Kwara State, Nigeria. In International journal of economic and development issues. Vol. 3 No. 1 of 2003. Ikot - Ekpere, Nigeria Development Universal Consortia

[5] Ariyo J.A. (1991) Rural Development Institutions: An overview of the factors which influence their Effectiveness. In Ariyo J.A (ed) Some perspective on environmental Management and Resource Development in Nigeria. Dept of Geography ABU Occasional paper ISSN 8065-4698.

[6] Cleaver K.M. (1993) A Strategy to Develop Agriculture in sub sahara Africa and a focus for the World Bank. Washington D.C. The World Bank

[7] Kolawole V.A (1989) underdevelopment of Nigerian irrigation system: design faults or system mismanagement? In International journal of water Resources Development Vol. 5 No. 2 pp 22-28.

[8] Ladipo, .O \& Leigh A.O. (1979) An Economic Analysis of Government Resources use Efficiency at the farm level: the case of milk production at Agege and Ibadan. ODU- journal of west African studies, university of life press Nigeria No. 19 pp 157160

[9] Lyam, A.A.L (1990) Performance Evaluation of rural Development projects in Benue State, Unpublished PhD. Thesis, Dept of Geography, Ahmadu Bello University Zaria. Nigeria

[10] Ogunfowora, O Essang S.M \& Olayide S.O. (1975). Resource Productivity in traditional Agriculture: A case study of four Agricultural Division in Kwara State of Nigeria. journal of rural Econ. Development Vol. 9 No. 2. pp 119-120

[11] SaLau, A.T (1986) River basin planning as a strategy for rural development in Nigeria. journal of rural studies vol. 2 No. 4 pp 321-335

[12] United Nations (UN) (2001) Nigeria Common Country Assessment Nigeria, United Nations. 